\title{
不働態及 び局部腐食*
}

\author{
Z. A. Foroulis** \\ Passivity and Localized Corrosion* \\ **Exxon Research and Engineering Company
}

\begin{abstract}
Passivity and localized corrosion is discussed using iron, iron-chromium, iron-chromium-nickel alloys and aluminum as examples. A brief description is given of the prevailing ideas regarding the nature of the passive film and the processes by which its protective properties are lost when breakdown of passivity and localized corrosion occurs.
\end{abstract}

\section{1. 緒言}

不働態は，数々の 金属及び合金の 表面の 状態を意味 し，腐食性環境との相互作用により，特殊な性質をるつ 表面皮膜の形成によって特徵づけられる。皮膜の形成に よって，金属または合金表面は，腐食に対して抵抗を示 すようになる (不働態化)。不働態化現象は, 多くの活 性な金属及び合金を，工業材料としてうまく利用するた めの基礎である。不働態の破壊は, 孔食, すきま腐食, 粒界腐食または応力腐食割れのような局部腐食によって 起こる。

\section{2. 不働態の定義}

18世紀初頭，鉄は，希硝酸中では，すぐに反応するけ れぞも，濃硝酸中では，外見上腐食しないことが観察さ れた1)。この耐食的状態は，鉄を濃硝酸から取り出し， 希硝酸に浸漬させた時にも保たれていることが分かっ た。この鉄の耐食的状態を “不働態” 状態と呼んだ2)。 Faraday $は^{3)}$, これと同様の鉄の不働態が，アノード分 極によっても得られることを示した。

最も広く受けいれられている不働態の定義は, Uhlig2) そよって，次のように記述されている。すなわち，標準 電位系列飞损いて，活性な金属が，その系列に打いて貴 な金属（貴な電位，腐食速度が小さい）の電気化学的挙 動を示すとき，不働態であるといら。不働態を示す金属 及び合金の例として，酸化性環境に批けるクロム，ニッ ケル, ステンレス鋼, 鉄, アルミニウム, チタンなどの

*この論文は, 1985 年 5 月 $23 \sim 27$ 日にわたり開 催された第 4 回 アジア太平洋腐食会議で行った 基調講演をまとめたものである。

** P.O. Box 101, Florham Park, New Jersey 07932, U.S.A.

*** 訳者：能登谷武紀 北海道大学工学部金属工学科 (₹060 札幌市北区北十三条西八丁目)

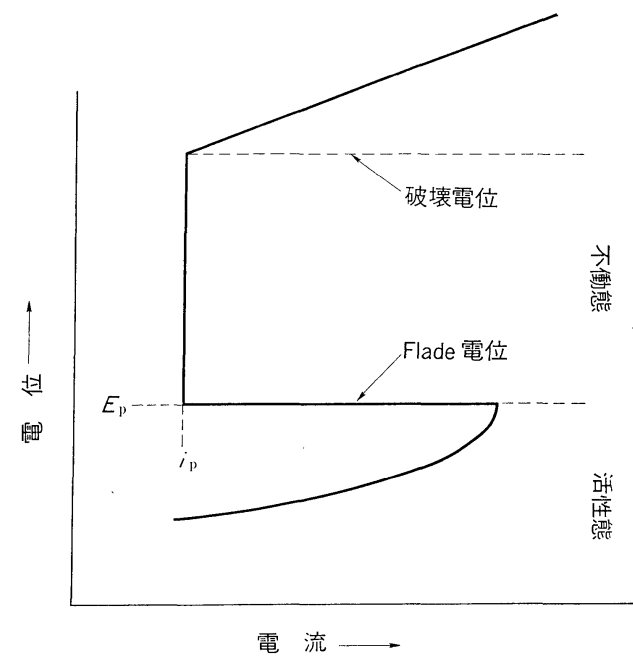

図 1 定電位アノード分極曲線の眓解

金属があげられる。不働態を示す系は，図 1 亿示される 型の分極曲線を示すことによって特徴づけられる。

この図は，電位に対する電流の変化を示す定電位分極 曲線である。この曲線の下の部分は，金属が活性で腐食 している電位域を示す。曲線の中央部は，不働態域とし て知られ, Flade 電位または不㗢態化電位 $\left(E_{p}\right)$ とよっ て活性域と分けられている。不働態域では，金属は不働 態であり，その溶解速度は， $I_{p}$ で示され，これは極めて 小さい。より高い電位になると，不働態域は，いわゆる 破壊電位によって終了する。破壊電位では，その電位か らより大きな電流が流れ，局部腐食が開始する。この現 象については，次の項で詳しく述べる。

この罒は，C. Wagner ${ }^{3)}$ とよって報告されたもので, 不働態について，広い意味での現象論的定義を示してい る。その主旨は，次のと拈りである。金属の電位を，よ り正の方向へ，換言すれば，よりアノード值へ増加させ 
ていくと, アノード溶解速度が, 低いアノード電位で観 察される值より小さな値へ急に減少する。その電位に到 達したとき，金属は，不働態になる。このアノード溶解 速度の減少は，熱力学的には金属の溶解傾向が高いにも かかわらず，不働態皮膜が形成されるためによって起こ る。

\section{3. 不働態皮膜の性質}

鉄，クロム，鉄-クロム及び鉄ークロムーニッケル合金 のような金属及び合金上の不働態皮膜の性質は，過去数 十年にわたり，文献に沶いて，議論の的となってきた。 この不働態皮膜の性質に関しては，二つの共通した見方 がある。まず，第一に不働態皮膜は，金属酸化物のよう な難溶性反応生成物から成る 三次元的拡散障壁層 であ りこれが金属または合金とその環境とを分離すること によって，金属または合金の溶解速度を低下させるとい ら見解である。第二に，不㗢態は，二次元的化学吸着皮 膜㲹起因するという見方である。例光ば，酸素またはそ の他の化学吸着種皮膜が，金属の活性溶解飞必要な通常 の吸着水分子と置換すること飞よって, アノード溶解速 度を低下させるといら見解である。

不働態鉄に対する三次元理論または酸化物皮膜理論を 支持する論文は， Evans ${ }^{4)}$ 及び Vernon ${ }^{5)}$ とよる不働態 鉄からの薄い酸化皮膜の分離にはじまり，過去 60 年間 にわたる一連の広範囲な実験結果によって証明されてい る。この酸化皮膜は, 剥離させた皮膜を検查し, 分析す るために，不働態鉄を沃素一沃化カリウム水溶液または 沃素ーメチルアルコール溶液中に浸漬して，不働態皮膜 を溶液表面上に浮上させる方法で得られた。Mayne と その共同研究者達 ${ }^{6), 77}$ は，鉄から分離した皮膜を電子線 回折によって調べた。この鉄は，前もって通気した水酸 化ナトリウム溶液またはクロメート中で不働態化させた ものである。彼らは，この皮膜の主成分として, $\gamma-\mathrm{Fe}_{2} \mathrm{O}_{3}$ が存在することを報告した。

このような初期の実験に引続き，かなりの期間，鉄の 不働態に関する研究は, 鉄の不働態化電位 (Flade 電位) の測定 ${ }^{8) ~ 10)}$ 及び定電位電位・電流曲線 ${ }^{11)}$ 14) 亿関する研

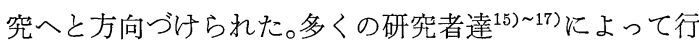
われたこの方面の研究及びこれに関連した研究は，鉄の 活性化または不働態化とその $\mathrm{pH}$ 依存性を調べることに より,Flade 電位の再現性を明らかにした。その結果, 不 働態鉄の Flade 電位測定値が, 3 種の既知の鉄酸化物, すなわち, $\mathrm{FeO}, \mathrm{Fe}_{3} \mathrm{O}_{4}$ または $\mathrm{Fe}_{2} \mathrm{O}_{3}{ }^{14)}$ 、について, ど の組合わせの鉄/鉄酸化物電極系に対する理論電位值よ りも，約 $0.66 \mathrm{~V}$ も貴であることが分かった。この理論 值と実験値のずれは，酸化物・皮膜理論の提唱者によ り, 理論的飞説明された。彼らは, 酸化皮膜中 ${ }^{18)}$ に, 高
い電位勾配 $\left(10^{6} \mathrm{~V} / \mathrm{cm}\right)$ が存在すること，または， $\gamma-\mathrm{Fe}_{2} \mathrm{O}_{3}$ 皮膜は, 下地の $\mathrm{Fe}_{3} \mathrm{O}_{4}$ 層と平衡初沈ると想定した。 過去 20 年間に, 直接観察が可能な, 進歩した実験法 を導入することによって，鉄の不働態に関する理解は， かなり深められた。不働態化する前に超高真空中で調製 した鉄表面 ${ }^{19)}$ を用いた数々のエリプソメトリーによる研 究及び不働態化した鉄箔 ${ }^{20)}$ の電子線回折による研究によ っ，Kruger は，不働態皮膜が三次元的結晶格子をも つことを強く示唆した。更に, ラジオトレーサー法によ り，不働態皮膜が，その外層に水素を含むことを示し た ${ }^{19)}$ 。Sato 並びに共同研究者 ${ }^{21)}$,22)及び O'Grady ${ }^{23)}$ に よる最近の研究によると，鉄上の三次元的不㗢態皮膜 は，完全な化学量論的酸化物皮膜でないという証拠をあ げている。O'Grady のメスバウアースペクトルによる 研究では, 鉄上の不働態皮膜は, 無定形または多分, ポ リマー状に結合していることを示した。鉄上の不働態皮 膜中に “結合水” が存在するといら証拠が Sato らによ って示された。これらの研究者達は, 実験事実に基づ き, 鉄上の不働態皮膜に対する種々のモデルを提案し た。皮膜中には, 非化学量論的組成が存在すること及び アニオンが含まれていることなどを明らかにした。

酸素または無機の酸化性アニオンが, 鉄表面上に吸着 するという見解 $\left.{ }^{24)}, 25\right)$ に, 証明が必要であり, 化学量論 的または非化学量論的酸化物の存在なしに鉄が不働態に 達するに充分な根拠は, やや弱い。その根拠恃, 主とし て鉄に対する Flade 電位についての熱力学的計算に基 づく ${ }^{24)}$ もであると同時に, 鉄上の不働態皮膜が, $\mathrm{NaOH}$ 溶液中で, クロマイト $\left(\mathrm{CrO}_{2}^{-}\right)$をクロメート $\left(\mathrm{CrO}_{4}{ }^{2-}\right)$ に酸化させることができるという事実に基づいてい $3^{26)}$ 。

鉄の不働態皮膜についてのクーロメトリー測定 ${ }^{1)}$ とよ ると, 約 $0.01 \mathrm{C} / \mathrm{cm}^{2}$ の皮膜厚は, 表面粗度を 4 とする 々吸着酸素の約 3 分子層に相当する。更に, 種々の不働 態化アニオン, 例えば, $\mathrm{CrO}_{4}{ }^{2-}, \mathrm{NO}_{2}{ }^{-}$などを含む水溶 液中で不働態化した鉄に対し，その Flade 電位及び不働 態皮膜厚（クーロメトリー測定に基づく）は，アノード 分極から得られたものと同じであると報告されている。 これらの観察結果は，酸素または酸化性のアニオンのよ らな他の溶媒種の吸着が，鉄の不働態化をひき起こすに 充分であると主張する考方方に対して，非常に弱い資料 となる。吸着によって鉄を不働態化させるためには，単 分子層の一部（すべてのキンク部分を塞ぐに必要）また は最悪の場合でも，単分子層（金属表面を完全に覆うた めに必要）で充分不働態が達せられなければならない。

吸着一皮膜理論にとって強味である一つの資料は, ク 口ム及び鉄-クロム合金について認められる。 $1 \mathrm{~N} \mathrm{H}_{2} \mathrm{SO}_{4}$ そ拈ける鉄ークロム合金を用いた Frankentha127) のクー 
ロメトリー研究において，不働態化するに充分な最小の 皮膜厚は， $360 \mu \mathrm{C} / \mathrm{cm}^{2}$ であり，これは，約 $30 \%$ の被 覆率に相当する。不働態に達するためのクロム上の不働 態皮膜は，単分子層でも，それ以下でも構わないことが Gershaw 及び Sirohi ${ }^{28)}$ によって示された。しかし， 彼らは, エリプソメトリー, 定電位法及びクーロメトリ 一による研究によって, $\mathrm{Cr}_{2} \mathrm{O}_{3}$ の単分子層が表面を覆っ た時点でクロムは不働態化すると結論した。

鉄・クロム及び鉄ークロムーニッケル合金の不働態開始 飞関係する最初の皮膜の性質が如何なるものであるうと も, 不働態化電位 (Flade 電位) より貴の電位では, 不 働態皮膜は時間と共に厚くなり，更に，カソード還元抵 抗が増大するといらことは，明白な実験事実である。ま た，少なくとも定常状態に执いて，ょり安定な形では， これらの合金の不働態皮膜は，酸化物の形をとること 多，疑問の余地はない。

これらの合金の安定な不働態皮膜は，大部分，非結晶

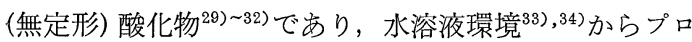
トンさえ取込んでいるといら証拠が続々とあげられてい る。例えば, McBee と Kruger ${ }^{30}$ ) は，電子線回折を用 いて，数種の鉄-クロム合金の不働態皮膜の 構造を決定 し，不働態皮膜は，ク口ムの増大と共に非結晶性にな り，そのことはまた，耐食性を向上させることを示し た。Hoar ${ }^{29)}$ は，非結晶の不働態皮膜の方がより耐食的 であると指摘した最初の人物であり，この考光方は，更 飞広がり，他の人々によっても論ぜられた。しかしなが ら，非結晶酸化物皮膜が，明らかに有利であるにもかか わらず，依然として，これらの合金上に形成された不働 態皮膜の化学的及び構造上の性質について，研究者間て 完全な一致をみていないといら点を指摘しなければなら ない。

最後に，アルミニウムの例をみてみよう。アルミニウ ムは，標準電位列の中では，非常に活性な金属である が，空気または水にさらすと容易に不働態化する。アル ミニウム上の不働態皮膜は，約 $2 \sim 10 \mathrm{~nm} \quad(20 \sim 100 \AA)$ の厚さをもつアルミニウム酸化物から成ることが一般に 容認されている。この酸化皮膜の化学的及び構造上の性 質は，環境及び皮膜形成過程の条件（温度，電圧）に依 存する。空気中で生成した皮膜及び室温の水の中にさら すことによって生成した皮膜では，アルミニウム上の不 働態皮膜の外側が非結晶皮膜から成る非結晶酸化物であ り，非結晶皮膜は，擬似べーマイトに変わるという点 で，妥当な合意が得られている。擬似べーマイトは，べ ーマイトに比べて,あまりはっきりしない結晶型を示し, 長時間，低温飞さらすと ${ }^{36)} \alpha-\mathrm{AlO}(\mathrm{OH})^{35) ， ま た は ハ ゙ イ ~}$ ヤライト $\left(\mathrm{Al}_{2} \mathrm{O}_{3} \cdot 3 \mathrm{H}_{2} \mathrm{O}\right)$ に変わる。

不働態皮膜についての他の二, 三の重要な性質は, その
機械的性質と電気的性質である。柔軟性をるった不働態 皮膜は, 残留応力または外部から加兄られる応力によ り，不働態が機械的に破壊するのを防ぐ傾向があるとい ら理由から，一般に好ましいと考兄られている。種々の 金属及び合金を使った Bubar 及び Vermilyea ${ }^{37)}$ の研 究では, 非結晶の不働態皮膜は, 結晶性のものより柔軟 性に富んでいることを示している。しかし，この点につ いては，任意の合金系に対して一般的な結論を引出すた めには，更に研究を重祆る必要がある。

不働態皮膜について，理論上及び実際上極めて重要な もら一つの性質は，電気伝導性である。多くの金属及び 合金上の不㗢態皮膜を用いて，酸化還元反応を行うこと ができることは，よく知られている38) 40)。しかし，電気 的性質並びに不働態皮膜を通る伝導機構については，依 然として，議論の余地あるテーマである。この件に関す る解説記事の中で，Sato ${ }^{41)}$ は，多くの金属及び合金に 関する現在の知識によれば，不働態皮膜の電気的性質 は，半導体から絶縁体の範囲にまたがり，不働態皮膜が 充分薄い場合, 酸化還元反応は, 電子トンネル機構によ って進行すると指摘している。

\section{4. 不働態皮膜生成及び成長機構}

不働態皮膜生成機構は，まず厚さが $20 \sim 30 \AA$ 程度の 極めて薄い不働態皮膜が形成され，これに引続き不働態 皮膜が厚くなるものと考兄られている。文献に報告され ている研究のほとんどが，この初期不㗢態皮膜の生成機 構を取扱っている。皮膜の成長過程については，余り広 範囲に研究されていないためか，よく理解されていな い。

皮膜生成過程に対しては，これまで二つの重要な機構 が提案されている。第一の機構は, 溶解一沈殿機構 41 , ,42 として知られて括り，皮膜生成が起こる表面で，金属イ オンが飽和濃度に達するまで，活性溶解がぞんぞん進む ものと仮定する。この機構は，Muller ${ }^{41)}$ が最初に提案 したもので品るが，広くは受入れられていない。これよ

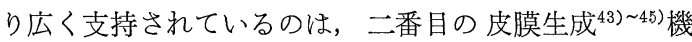
構であり，アノード溶解と皮膜生成が，同時に起こると 仮定する。この種の機構では，金属または合金の溶解 は，皮膜に覆われていない表面で起こる。

不働態皮膜成長機構は，充分に明らかにされていない し，文献に報告されている結果は，幾分矛盾している。 Vetter ${ }^{46)}$ 及び Weil ${ }^{47)}$ は，硫酸中の鉄の不働態皮膜成 長が，逆対数則に従らことを見出したけれぞも， Nagayama と Cohen ${ }^{48)}$ 並びそ Brasher と Kingsbury ${ }^{49)}$ は，各々，中性溶液及びクロメート溶液中の鉄 の皮膜成長は，対数則に従うと報告している。一方，最 近, Gershaw と Sirohi ${ }^{28)}$ は, クロム上の不働態皮膜 


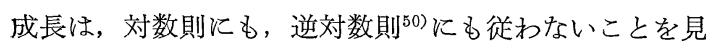
出した。

観測される不働態皮膜成長速度を説明するために，二 つの理論モデルが頻繁に使われている。逆対数則を説明 するために, Cabrera 及び Mott ${ }^{511}$ によって提案され た電場補助イオン伝導モデルが使われ，対数則を説明す るために，Sato 及び Cohen ${ }^{52)}$ によって示された置換 モデルが使われている。しかし，これらのモデルが観察 された速度論すべての面を説明するのに適当か否かにつ

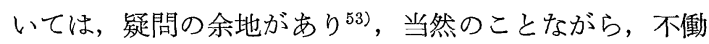
態皮膜成長 ${ }^{54), 55)}$ 機構について, 我々の理解を深めるため には, 更に, 理論的研究が必要であり, 恐らく速度論的 測定以外の方法, 例えば，スペクトル解析法などを用い た実験的研究が必要であると思われる。

\section{5. 不働態破壊}

緒言でも述べたよらに，不働態の破壊は，孔食，すき 間腐食, 粒界腐食及び応力腐食割れのよらな局部腐食を 生じさせる。一般に，不動態皮膜は，保護層として，次 のような過程によって損傷をらけまなな除去される。 すなわち, 電気化学的脱不働態化として知られている不 働態のアノード破壞, 化学的脱不働態化, 化学的皮膜溶 解, 多孔性皮膜の下地侵食, 酸化物の還元溶解及び機械 的応力などである。

アノード破壊は, 不働態破壞のごく普通の型である。 これは, 侵食性アニオンの存在する中性及びアルカリ性 溶液中で認められる。アノード破壊または電気化学的脱 不働態化は，不動態破壊の最もありふれた型なので，こ れに重点を和くことにする。不働態破壊の他の型につい ては, 一般に余り重要ではないので，簡単にふれること にする。化学的脱不働態化は, 侵食性アニオンの存在す る酸性環境に和ける電気化学的皮膜溶解之関連性があ る。化学的皮膜溶解には, 酸化物不働態皮膜の直接溶解 が含まれ，酸性またはアルカリ性の強い溶液において， 特殊な金属/溶液系にしか起こらない。不働態皮膜下地 溶解は，腐食性溶液にさらされている金属の皮膜に細孔 がある場合に起こる。その場合，細孔の底部及び皮膜と 金属の間で溶解が進行するため, 酸化物の結合がゆるめ られ, 結局, 剝離に至る。不働態皮膜の還元溶解は, 不 働態破壊のもら一つの機構であり, 幾つかの例で示され ているように, 不働態鉄酸化物が除去されるために起こ る。還元溶解過程を進行させるためのアノード電流は, 外部電源によって供給されるか, または, 鉄が溶解して いる場所の金属面から供給される。

最後に, 残留応力または引張り応力などの機械的応力 は，不㗢態皮膜に機峨的損傷を与えることになり，しば しば応力腐食割れの発生につながる。この現象は, 非常
に重要であるが, この解説の主旨から外れる。

次の項では, アノード不働態破壊を特徵づけるために 見出された幾つかの主要な観察結果について, 簡単に論 ずると共に，不働態の破壊を防止したり，または最小限 にとどめるための方法を指摘することにする。また，観 察結果を説明するために提案された幾つかの重要な理論 あるいはモデルを簡単に紹介しょう。しかし，この解説 では, これらの現象を詳しく論じないため, 読者は, こ

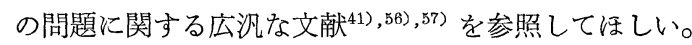

\section{6. 不働態破壊の実験的側面}

通常，孔食またはすき間腐食の原因となるアノード不 働態破壊は，発生した孔食またはすき間の初期過程及び 伝播または成長過程として記述されている。

\section{1 不働態破壊過程の開始}

アノード不働態破壊の開始は, 幾つかの主要な実験観 察結果によって特徴づけられる。

a.その電位なたはそれよりアノード側電位で不㗢態 破壊が起こる臨界電位 $E_{\mathrm{c}}$ が存在する。臨界電位より低 い電位では，金属は，不働態のままである。 $E_{\mathrm{c}}$ は，孔 食電位または，破壊電位として知られているが，この電 位は，幾つかの方法によって測定することができる。例 えば，定電位法，定電流法及び機械的表面引っかき法な どである。鉄, 鉄ークロム合金, 18-8 型ステンレス鋼及 びアルミニウムに対する臨界電位の典型的な值を表 1 に

表 1

\begin{tabular}{|c|c|c|c|}
\hline \multicolumn{4}{|c|}{ 孔食電位，V(SHE) } \\
\hline 金属／合金 & $0.1 \mathrm{NaCl}$ & $1 \mathrm{M} \mathrm{NaCl}$ & 文献番号 \\
\hline Iron & $0.48^{*}$ & & $60)$ \\
\hline $\mathrm{Fe}-12 \mathrm{Cr}$ & 0.20 & & 61) \\
\hline $\mathrm{Fe}-30 \mathrm{Cr}$ & 0.62 & & 61) \\
\hline $\mathrm{Fe}-18 \mathrm{Cr}$ & & $0.34 \sim 0.38$ & 62) \\
\hline $\mathrm{Fe}-18 \mathrm{Cr}-1 \mathrm{Mo}$ & & $0.40 \sim 0.46$ & 62) \\
\hline $\mathrm{Fe}-18 \mathrm{Cr}-2 \mathrm{Mo}$ & & $0.40 \sim 0.56$ & 62) \\
\hline $\mathrm{Fe}-18 \mathrm{Cr}-5 \mathrm{Mo}$ & & $0.76 \sim 0.80$ & 62) \\
\hline $\begin{array}{l}\text { 18-8 Stainless } \\
\text { Steel }\end{array}$ & 0.26 & & 61) \\
\hline Aluminum & -0.37 & & $63), 64), 65), 66)$ \\
\hline
\end{tabular}

$*$ in $0.5 \mathrm{M} \mathrm{SO}_{4}^{2-}$

示す。一般に，孔食電位は，鉄系合金に対しては，合金 量と共に増大し, アルミニウムの孔食電位は, ずっと低 い值をとる。

図 2 は, あらかじめアノード酸化した純アルミニウム の準動電位法によって得られた $0.1 \mathrm{~N} \mathrm{KCl}$ 溶液に扣け る臨界孔食電位を示している。破壊電位は, 孔食が開始 し, 電流が上昇し始める最も低い電位を示す。図 3 は, 


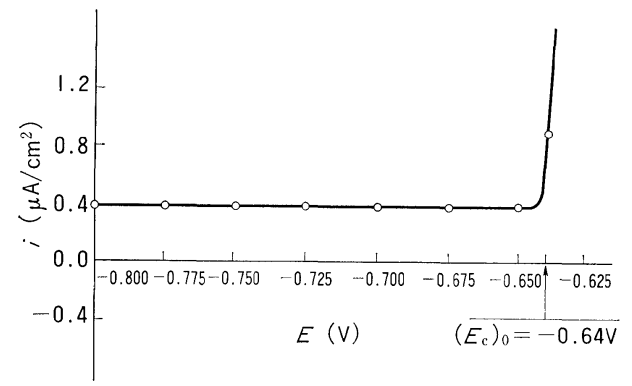

図2 あらかじめアノード処理した純アルミニウム の $25^{\circ} \mathrm{C}, 0.1 \mathrm{~N} \mathrm{KCl}$ 溶液中に打数定電 位臨界孔食電位の典型例

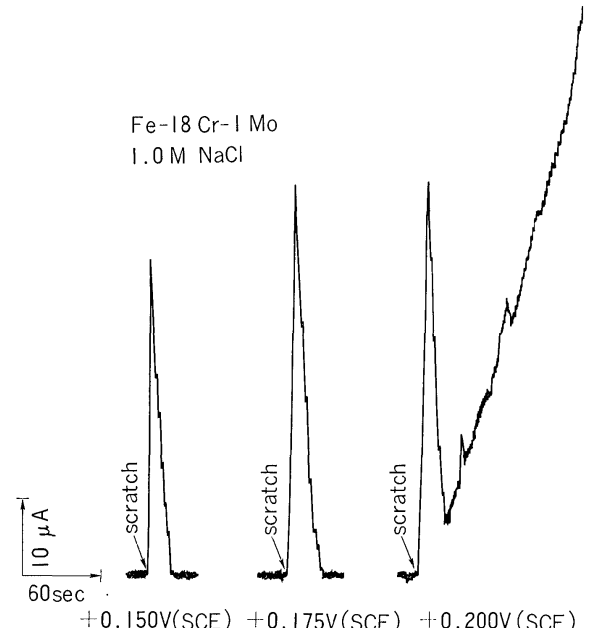

因 3 臨界孔食電位 $(0.2 \mathrm{~V})$ 近傍に和ける表面引っ かきによる電流変化

表面引つかき法によって決定した $0.1 \mathrm{M} \mathrm{NaCl}$ に打け る $\mathrm{Fe}-18 \mathrm{Cr}-1 \mathrm{Mo}$ 合金の臨界電位を示す。 $+0.200 \mathrm{~V}$ より低い電位では，表面を引搔くことによって変化する 電流は, 急速に不働態電流密度の值まで減少し, 不働態 が保たれる。+0.200 V の臨界電位では, 引搔きの後, 再不働態化するような挙動を示すけれども, 電流が増大 し続け，孔食が発生する。図 4 は， $0.1 \mathrm{~N} \mathrm{NaCl}$ に和け る 18-8 型ステンレス鋼の破壊電位及び $\mathrm{Na}_{2} \mathrm{SO}_{4}$ 添加 効果を示す。この破壊電位は, $\mathrm{SO}_{4}=$ 濃度の増大と共に 増大する。この効果は, Leckie 及び Uhlig により, 塩 化物イオンの吸着を妨害する $\mathrm{SO}_{4}=$ イオンの競合吸着及 び不働態破壊の開始によるものであると解釈された。

図 5は，18-8 型ステンレス鋼の不働態破壊に及ぼす $0.1 \mathrm{~N} \mathrm{NaNO}_{3}$ 中の塩化ナトリウム濃度増大の影響を示 す。 $\mathrm{Cl}^{-}$が存在しないと, 破壊電位を示さないことか ら分かるように不働態破壊は起こらない。塩化物イオン が存在する場合, その濃度が $1 \mathrm{M}$ 及び $0.5 \mathrm{M}$ では, それぞれ 0.2 及び $0.4 \mathrm{~V}$ の電位で不働態破壊が起こ

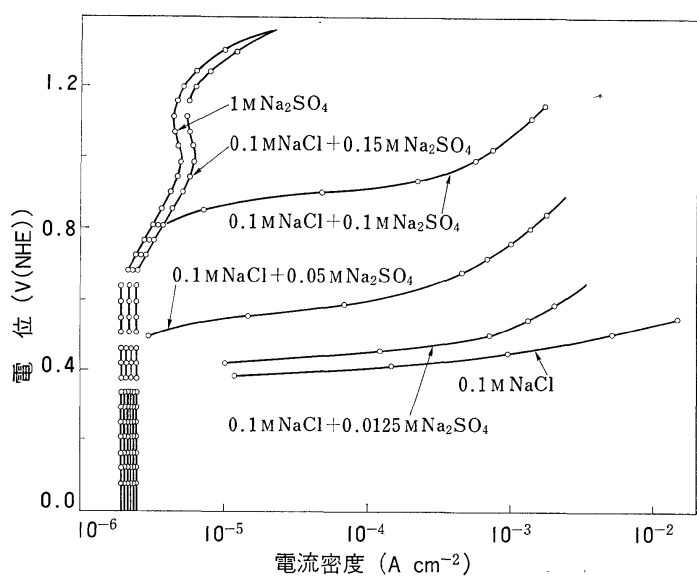

図 $40.1 \mathrm{M} \mathrm{NaCl}$ 溶液中に打ける 18-8 ステンレ ス鋼の定電位分極曲線に見られる $\mathrm{Na}_{2} \mathrm{SO}_{4}$ 添 加による皮膜破壊電位 $E_{\mathrm{c}}$ の貴化 $\left(25^{\circ} \mathrm{C}\right)$

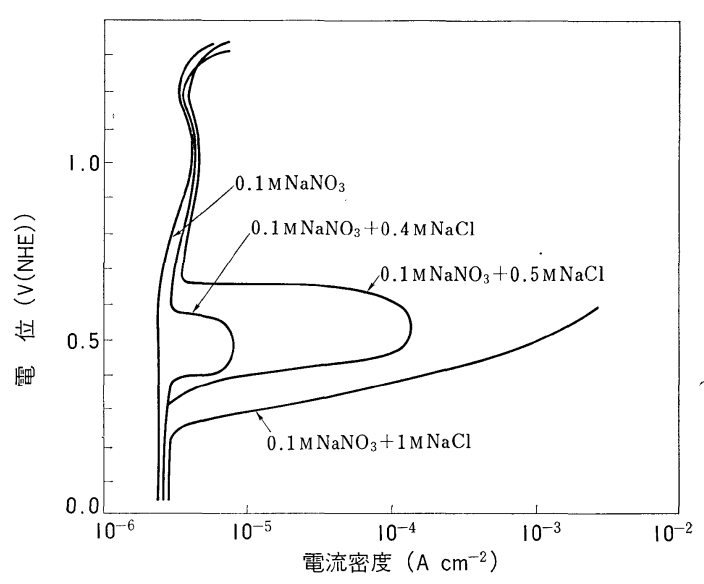

図 $5 \mathrm{NaCl}$ の含有量を変えた $0.1 \mathrm{M} \mathrm{NaNO}$ 溶 液中に括ける 18-8 ステンレス鋼の定電位分 極曲線 $\left(25^{\circ} \mathrm{C}\right)$

る。また, このデータは, $\mathrm{Cl}^{-}$濃度が低いときに, 酸化 性の $\mathrm{NO}_{3}^{-}$は, $\mathrm{NaCl}$ 濃度が $0.4 \mathrm{M}$ 及び $0.5 \mathrm{M}$ に対 し，それぞれ 0.6 及び $0.7 \mathrm{~V}$ の電位で, この合金を再 不働態化させることを示している。活性化アニオン及び 不働態化アニオンの共存下に和ける合金の再不働態化電 位は，抑制電位 $E_{\mathrm{i}}$ とよばれている。

表 1 に示してあるデータは, 定電位アノード分極曲線 から得られたものである。臨界電位または破壊電位は, 侵食性アニオン濃度の増大及び温度の上昇と共に減少す

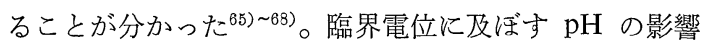
については，一般に一致していない。ある系では，その 影響が小さいが，別の系では，その影響が大きいと報告 されている。

b. 不働態破壞の開始は，不働態皮膜破壞及び孔食開 


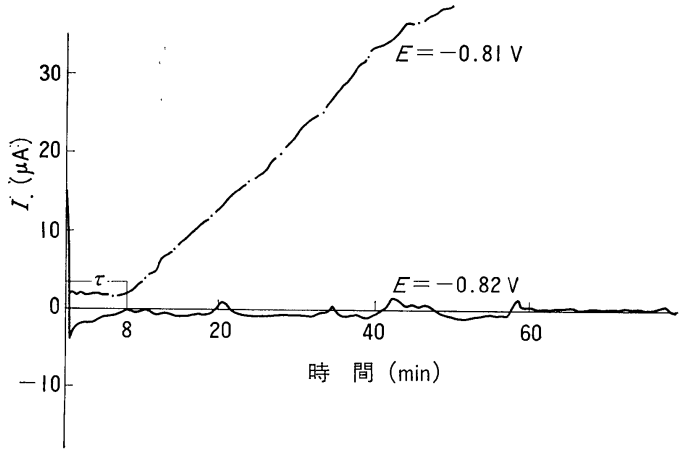

図 $63 \mathrm{M} \mathrm{KCl}$ 溶液 $\left(25^{\circ} \mathrm{C}\right)$ 中で $-0.81 / \mathrm{V}(\mathrm{SCE})$ 及び $-0.82 \mathrm{~V}(\mathrm{SCE})$ に保持した純アルミニ ウムの典型的電流一時間曲線

始までに要する時間を示す誘導期間の存在によって特徵 ら゙けられる。図 6 は, 孔食核発生のための潜伏時間の存 在を示す。この図は，ほぼ中性の $\mathrm{pH}$ に沶いてアノー ド酸化したアルミニウムの電流に及ぼす臨界破壊電位 $\left(E_{\mathrm{c}}=0.81 \mathrm{~V}\right)$ 及びその電位より低い電位における $\mathrm{Cl}^{-}$ 添加効果を示す。潜伏時間と呼ばれる時間 $\tau$ は, 電流の 増大及び孔食はすぐ溌生するものではなく，孔食が 開始するためにある時間が必要であることを示す。この 誘導時間は, 電位の減少 ${ }^{77), 78)}$, 温度の低下 ${ }^{79), 80)}$ そして 侵食性イオン濃度 ${ }^{79)}$ 舟1) の低下と共に長くなることが明 らかにされている。自然条件で核生成した孔食の自然腐 食電位は, 少なくとも誘導時間の間は, 破壊電位 $\left(E_{\mathrm{c}}\right)$ より貴になっていた筈である。

c. 3 番目の観察結果は, 破壊過程の開始及び伝播飞 は， $\mathrm{Cl}^{-}$またはその他の八ロゲンイオンのような侵食性 アニオンが必要であるということである。以前は，一般 に塩化物イオンだけが侵食性イオンであると考光られて

表 2

\begin{tabular}{lcc}
\hline \hline 金属/合金 & 侵食性アニオン & 文献 番 号 \\
\hline Iron & $\mathrm{Cl}^{-}$ & $69)$ \\
& $\mathrm{Br}^{-}$ & $70)$ \\
& $\mathrm{I}^{-}$ & $70)$ \\
& $\mathrm{ClO}_{4}^{-}$ & $71)$ \\
& $\mathrm{SO}_{4}^{-}$ & $60)$ \\
\multirow{5}{*}{ Stainless Steel } & $\mathrm{Cl}^{-}$ & $61), 72)$ \\
& $\mathrm{Br}^{-}$ & $72)$ \\
& $\mathrm{SCN}^{-}$ & $73)$ \\
& $\mathrm{Cl}^{-}$ & $63), 64), 65), 66)$ \\
& $\mathrm{Br}^{-}$ & $63)$ \\
& $\mathrm{I}^{-}$ & $63)$ \\
& $\mathrm{ClO}_{4}^{-}$ & $74)$ \\
& $\mathrm{NO}_{3}^{-}$ & $75)$ \\
& $\mathrm{SCN}^{-}$ & $76)$
\end{tabular}

いた。しかし, 後になって, 硫酸イオン, 過塩素酸イオ ン，硝酸イオンなどのような無害のアニオンと考兄られ ていたものも, 不働態破塤を起こしうることが分かっ た。表 2 に, 不働態を破壊させる侵食性アニオンについ ての典型的なデータを集めた。この表から，この論文で 注目している極めて不活性の酸化物を形成する金属及び 合金に対し，強酸のアニオンのみが，不働態破壊をひき 起こすのに有効であると結論できる。

d. 4 番目の重要な実験観察結果は，不働態の破壊及 び孔食の開始は，常にと言うわけではないが，極めて局 部的な位置に起こることが観察されている。不働態破壊 は, 酸化皮膜のきず, 介在物, 粒界, 第二相析出物の位 置に起こりやすい。

これまでの数々の項目で論じた不働態破壞過程に関す る重要な実験観察結果を図 7 亿まとめた。図 7 の左上(I) のグラフは, アノード不働態破壊電位 $E_{\mathrm{c}}$ の動電位法に よる定義を示す。この破塤電位は，電流が，不働態電流
( I )

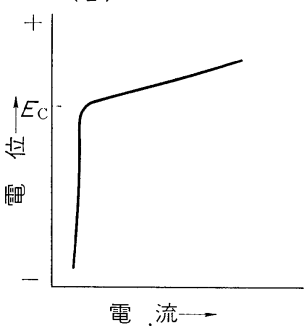

(III)

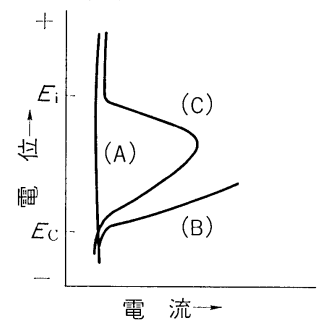

(II)

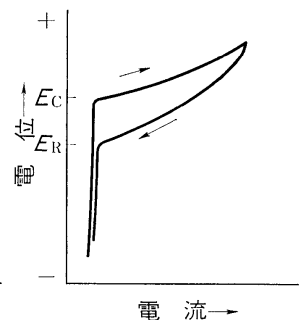

(IV)

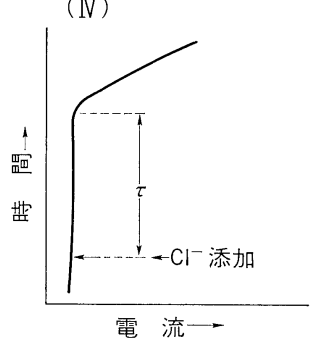

図 7 皮膜破壊プロセスに基づく分極曲線の型

值を超えて增加する電位であり，その電位を超えると孔 食が発生する。この図の左下 (III) のグラフには, 活性 化アニオンと不働態化アニオンが, 共に試験溶液中に存 在する場合のアノード破壊電位 $\left(E_{\mathrm{c}}\right)$ 及び抑制電位 $\left(E_{\mathrm{i}}\right)$ を示してある。右下 (IV) のグラフは, 臨界破壊電位に おける不働態破壞過程の開始に対する潜伏時間 $\tau$ の定義 を示している。

右上（II）のグラフは，破壊電位を超えた後に，かな り活性な電位まで繰返し，電位を掃引させた。折返し電 位掃引曲線は, かなりのヒステリシスを示し, 電流が元 の不働態電流值に減少する電位を $E_{\mathrm{R}}$ とする。 $E_{\mathrm{R}}$ は, 
再不働態化または保護電位として知られている。 $E_{\mathrm{R}}$ と $E_{\mathrm{c}}$ の間の電位に括いては，孔食は伝播するけれども， 新たに発生はしない。 $E_{\mathrm{R}}$ より低い電位では，孔食は発 生も伝播もしない。 $E_{\mathrm{c}}$ より高い電位では，孔食が発生 し，伝播する。

再不働態化電位 $E_{\mathrm{R}}$ の存在は, 孔食が発生してから, アノード方向へ電位を掃引させる間に, 閉塞アノードが 形成されることにより生ずるるので，電位を折返す間 に, この曲線は, 閉塞アノードを特徴づける径路をたど る。

\section{2 不働態破壊過程の伝播}

孔食発生過程の場合のように, 破壞過程で始まる孔食 または腐食すき間の伝播あるいは成長は，四つの重要な 実験観察結果によって特徵づけられる。次の項目では, これらのことについて述べる。

a. この過程では，孔食またはすき間が成長を続ける 最も低い電位である再不㗢態化電位をたは保護電位 $E_{\mathrm{R}}$ が存在する。 $E_{\mathrm{R}}$ は, 酸性度及び塩化物濃度 ${ }^{82}$ と共に変 化する孔食内部表面の実測電位に近いと言われている。

b. 多数の実験観察結果, 孔食及びすき間内部の溶液 は，バルクの溶液よりるずっと低い $\mathrm{pH}$ 及びょり高い イオン濃度にあることを示している。例光ば，ほぼ中性 の $\mathrm{pH}$ を示すバルク溶液中にさらされた鉄及びアルミ ニウムの孔食内部では, pH が 3.5 といら低い值が測 定されている。同様に，304 型ステンンス鋼に生成した 孔食では, $\mathrm{pH}$ が 1 より低く, 塩化物イオン濃度は, $6.2 \mathrm{M}$ むの高い值になっていることが分かっている83)。

c. 孔食またはすき間内部及びその周辺部の金属表面 上の電流と電位の分布は，孔食またはすき間の伝播にと って重要である。孔食内部では，活性状態が保たれ，不 働態金属の電流密度より最大 6 桁も大きな電流密度が観 測されている。不働態にある外部と, 活性な孔食内部の 間の分極は, 潘とんど全部，外部の不働態表面が分担し ている。

図 8 法, $0.05 \mathrm{M} \mathrm{Fe} \mathrm{NH} \mathrm{NH}_{4}\left(\mathrm{SO}_{4}\right)_{2} \cdot 12 \mathrm{H}_{2} \mathrm{O}+0.56 \mathrm{M}$ $\mathrm{NH}_{4} \mathrm{Cl}$ 溶液に浸漬されたステンレス 鋼上に形成された 部孔食の内及びその周辺部電解液に抢けるアノード及び カソード電流分布を示す。この図は， Rosenfeld 及び Danilov ${ }^{84)}$ の研究で紹介されたものであるが，ほとん どの分極が，孔食のまわりの不働態域に乱けるカソード 反応で起こっていることを示している。塩化物溶液中 で，304 型ステンレス鋼に自然発生した孔食に関する Jones 及び Wilde ${ }^{85)}$ による研究でも，孔食またはすき 間アノードは，ほんの 2，3 mV しか分極されないのに 比べ, 外部の不働態カソードは, 試料の腐食電位全体に 対し， $150 \mathrm{mV}$ 以上分極されることを示している。この 事実は, 以前に得られた結論 ${ }^{22)}$ とも一致し, 再不働態化

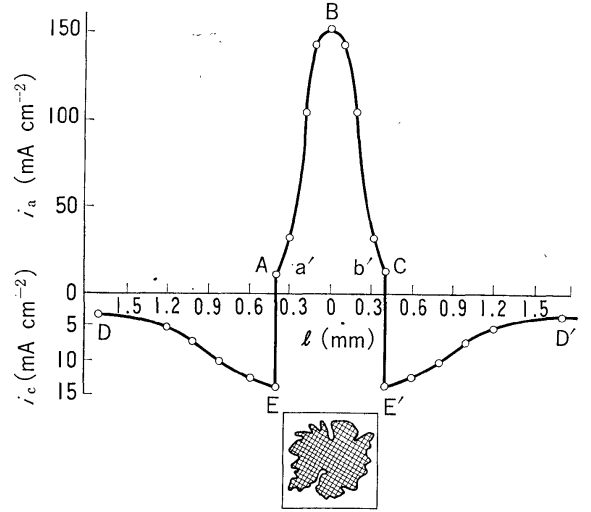

図 $80.05 \mathrm{M} \mathrm{FeNH}_{4}\left(\mathrm{SO}_{4}\right)_{2} \cdot 12 \mathrm{H}_{2} \mathrm{O}+0.56 \mathrm{M} \mathrm{NH}_{4} \mathrm{Cl}$ 中に拈けるオーステナイト系ステンレス鋼のピ ットの中及び周辺での電流分布

電位または保護電位 $E_{\mathrm{R}}$ が，孔食内部の金属表面の電位 に極めて近いことを示す。

不働態表面上での酸素還元は，通常，カソード反応で ある。自然に発生した孔食のまわりの不働態表面は, カ ソード反応を維持できなければならない。このことは， 不働態皮膜が，適当な電子伝導性をもっていることが必 要であることを意味する。例觉ば，アルミニウム及びア ルミニウムーマグネシウム 合金上飞生成する不働態酸化 皮膜は，良好な電子伝導体ではない。この事実は, 恐ら く，これらの合金の孔食電位が低いにもかかわらず，海 水中では優れた耐食性を示するのと思われる。

d. 最後に述べる重要な実験観察結果は, 再不働態化 電位 $E_{\mathrm{R}}$, 閉塞アノード電位 $E_{\mathrm{corr} ・ \mathrm{~A}}$ 及び孔食の自然成 長の間の関係についてである。

塩化物溶液に括いて, 再不働態化電位 $\left(E_{\mathrm{R}}\right)$ 及び閉塞 した孔食の腐食電位 $\left(E_{\mathrm{corr} \cdot \mathrm{A}}\right)$ の間の関係は，ほ核次式 で表すことができる。

$$
E_{\mathrm{R}} \simeq E_{\mathrm{corr} \cdot \mathrm{A}}+\eta \simeq E_{\mathrm{corr} \cdot \mathrm{A}}+\beta_{\mathrm{a}} \log \frac{i_{\mathrm{a}}}{i_{0}}
$$

ここでクは，外部の不働態表面と対になることによっ て, 閉塞アノードに生ずるアノード活性化過電圧であ る。 $\beta_{\mathrm{a}}$ は, アノード Tafel 定数 $(\simeq 30 \mathrm{mV}), i_{\mathrm{a}}$ 及び $i_{0}$ それぞれアノード電流密度及びアノード交換電流密度で ある。

式（1）から，電位が $2,3 \mathrm{mV}$ 低い值に移動しただけ でも， $E_{\mathrm{R}}$ は，孔食内の金属のアノード溶解速度を隇少 させるのに顕著な影響をもつことが分かる。例えば，電 位が $30 \mathrm{mV}$ 及び $60 \mathrm{mV}$ 活性側の $E_{\mathrm{R}}$ 一移動すると, 孔食内部のアノード溶解 (アノード電流密度) は, 各々, 10 倍及び 100 倍減少することになる。

孔食またはすき間が成長するため，または，その活性 を持続するために閉塞アノード部から腐食生成物が連続 


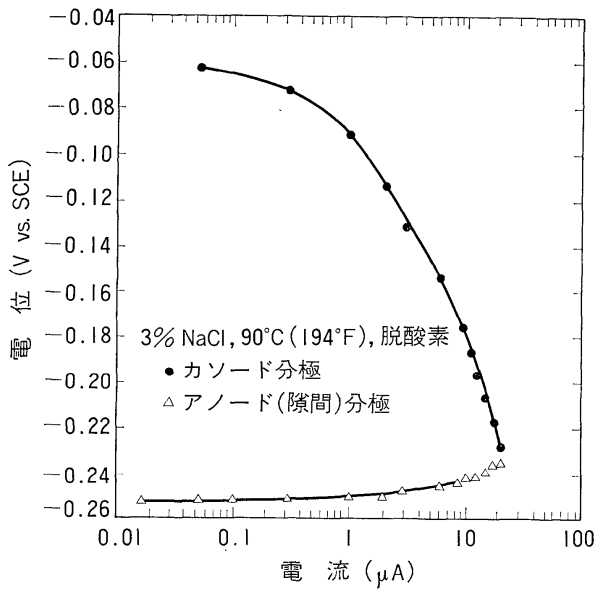

図9304 鋼ステンレス鋼の㗂間のアノード分極と不 働態皮膜のカソード分極

的に移動する。従って, 腐食生成物が, アノード溶解反 応により連続的に供給されるために, 閉塞セル内部の酸 性度及び塩化物塩濃度が維持される。孔食内部のアノー ド溶解速度が少しでも減少すると, 閉塞アノードの活性 は，著しく低下する。

再不㗢態化電位または保護電位 $E_{\mathrm{R}}$ は, 閉塞アノード 内の酸性度及び塩化物塩濃度の増大と共に減少するた め， $E_{\mathrm{R}}$ は，金属または合金に特有な性質ではなく，合 金を特性づける際には注意して用いねばならない。孔食 及びすき間腐食の両方に対して，最も不変の $E_{\mathrm{R}}$ の值 は，主な合金元素の塩化物塩が飽和している溶液に括け るその合金の腐食電位と一致するであろう。

\section{3 不㗢態破壊理論またはモデル}

次の項では,アノード不働態破壊過程を説明するため に提案された最も重要な理論またはモデルを簡単に紹介 する。

\subsection{1 競合吸着モデル}

この理論は, Uhlig's4) 及び Kolotyrkin ${ }^{65)}$ にっって示 されたもので，金属表面上の侵食性アニオンの競合吸着 が，不働態破壊及び孔食開始に対する重要な条件である と考える。このモデルによると, 孔食は, 金属表面上で 侵食性アニオンと酸素のよらな既に吸着している不働態 化種と置換することによって開始する。また，その他の アニオンが存在する場合には，それらのアニオンは，表 面の特定の位置で $\mathrm{Cl}^{-}$と競争し，不働態破壊を抑制す るものと考觉ている。

\subsection{2 酸化皮膜のきず及び欠陷部における皮膜侵入}

このモデルは, 後述のすべてのモデルに共通している ことであるが，不㗢態皮膜は，三次元的であるとする。 このモデルは，最初，Evans ${ }^{86)}$ によって提案され，そ の後 Richardson 及び Wood ${ }^{87)}$ により, 再び強調され
たものである。侵食性アニオンは, 皮膜材料とのものに は少しも侵入しないが，きずまたはとの他の欠陷部に入 り込むことによって，金属の腐食を促進する。多くの場 合, 孔食核生成が，幾分でも酸化皮膜中の欠陷の存在と 関係があることを示す証拠はたくさんある。皮膜の欠陷 は，酸化皮膜中に，以前から存在しているか，あるい は, 皮膜破壞及び再不働態化といら動的な過程によっ て，絶觉ずつくられるであろう。

\subsection{3 アニオン移動モデル}

幾つかの機構が提案されて括り, 侵食性アニオンが, 欠陥またはある種のイオン交換過程により酸化物格子を 通って移動する。例えば, Hoar $5^{88)}$ は, 塩化物イオン を含む溶液に执いて, 臨界電位以上の電位で, 電場によ り活性化したアニオンが，不働態酸化皮膜の一つの点 で，皮膜の中へ入り込むことを示唆した。アルミニウム に対するアニオン移動及び酸化物皮膜污染モデルが， Pryor ら ${ }^{89)}$ にっても提案された。彼らは，アニオン移 動が，皮膜のイオン伝導性を低下させ，破壊を促進する カチオン空孔を生成することを示唆した。このモデル は, $\mathrm{SO}_{4}=, \mathrm{ClO}_{4}^{-}$または $\mathrm{SCN}^{-}$のよらな多原子侵食性 アニオンの影響を観察した結果と矛盾しない。これらの イオンが, 固体の酸化物層を通って移動するとは, 想像 し難いことである。

\subsection{4 化学的一機械的モデル}

Hoar $^{90)}$ は，不働態皮膜表面上に，侵食性イオンが吸 着するため, 界面の張力を低下させ, “ュロイド化” に 至るものと考えた。この“コロイド化” は, 吸着したア ニオンの相互反発力によるもので, 遂には, 不働態酸化 皮膜に割れを生じさせ，金属を腐食性アニオンにさらす ことになる。 Sato $^{91)}$ は，このモデルをより詳細に検討 し，発展させた。

\subsection{5 錯体一溶解モデル}

このモデルは, Hoar $5^{80)}$, Foroulis 及び Thubrikar $^{81)}$, Foroulis ${ }^{92)}$, Dallek 及び Foley ${ }^{93)}$ によって論 じられた。不働態皮膜/溶液界面上の少数の侵食性アニ オンの吸着が，酸化物格子カチオンと反応して活性化さ れた可溶性錯体を形成するものと仮定した。アルミニウ 么の場合, $\mathrm{Al}(\mathrm{OH})_{2} \mathrm{Cl}_{2}{ }^{-}$のような錯体が形成されるが, その寿命は短く, 再び生成される。従って, この錯体が 最初に形成された場所の酸化物皮膜は薄くなり, 薄くな った場所のアノード電場は，より強くなるので，更に錯 体形成反応が加速されやすく，不働態皮膜が局部的に薄 くなって穴があくまで, 同じ位置で酸化物溶解が促進さ

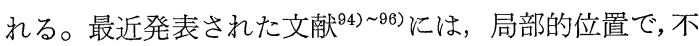
働態皮膜が薄くなる現象に対し，電気化学的証明がなさ れている。

不働態破壊は, 孔食の浪かに, 粒界腐食 ${ }^{76)}$, すき間腐 
食 $^{97), 98)}$ 及び応力腐食割れ(99) のような別の型の腐食の原 因となる。

不働態破壞過程に対し, 上に述べたモデルは，いずれ む, ある程度, 1 種の金属または数種の金属及び合金一 環境系に対し，実験的な証明がなされている。すべての 金属, 合金系及び侵食性アニオンについての実験結果に 対して説明しらる統一的な不働態破壊モデルはまだ報告 されていない。現在, 使用可能の表面分析法を使った研 究を一層行う必要があり, 将来この目的が達成されるも のと思われる。

\section{7. 不動態破壊の防止}

不働態破壊傾向を防止または最小にするために，三つ の主な対策が考えられている。まず，ステンレス鋼で は, $\mathrm{Cr}, \mathrm{Ni}, \mathrm{Mo}, \mathrm{Si}$ などの合金元素含量を増大するこ とによって合金の改良を行っている。これらの元素は, 破壊電位を上昇させる ${ }^{100,101)}$ 。次に, 不働態そのものを 強化し，不働態破壊傾向を抑制するインヒビターの使用 である。最後に, 定電位法によりアノード電位を Flade 電位より高く，そして破壊電位より低く制御する方法で ある。

\section{文献}

1) H. H. Uhlig: "Corrosion and Corrosion Control” John Wiley, New York p. 58 (1963).

2) C. Schonheim: Pogg. Ann., 37, 390 (1836).

3) C. Wagner: Corr. Sci., 5, 751 (1965).

4) U. R. Evans: J. Chem. Soc., 1024 (1927).

5) W. Vernon, F. Wormwell and T. Nurse: $J$. Chem. Soc., 621 (1939).

6) J. Mayne and M. Pryor: J. Chem. Soc., 1831 (1949).

7) J. Mayne, J. Menter and M. Pryor: J. Chem. Soc., 3229 (1950).

8) F. Flade: Z. Physik, Chem., 76, 513 (1911).

9) U. F. Frank: Z. Naturforsch, 4a, 378 (1949).

10) K. F. Bonhoeffer: Z. Elektochem., 47, 147 (1941); K. G. Weil, and K. F. Bohnhoeffer: Z. Phys. Chem., 4, 175 (1955).

11) J. H. Bartlett: Trans. Electroch. Soc., 87, 521 (1945); J. H. Bartlett and L. Stephenson: J. Electroch. Soc., 99, 504 (1952).

12) K. F. Bohnhoeffer, and Vetter, K. J.: $Z$. Physik. Chem., 196, 127 (1950).

13) K. J. Vetter: Z. Elektroch., 55, 675 (1951); 56, 106 (1952).

14) H. Beinert, and K. F. Bohnhoeffer: $Z$. Elektroch., 47, 536 (1941).

15) B. Kabanov, and D. Leikis: Acta Physichem. USSR, 21, 769 (1946).

16) B. B. Losev and B. Kabanov: Zh. Fiz. Khim., 28, 824, 914 (1954).

17) G. H. Cartledge: Z. Elektrochem., 62, 684
(1958).

18) K. Vetter: Z. Elektroch., 62, 642 (1958).

19) H. Göhr, and E. Lange: Z. Elektroch., 61, 1291 (1957).

20) C. L. Foley, J. Kruger, and C. L. Bechtodt: J. Electroch. Soc., 114, 994 (1967).

21) T. Noda, K. Kudo and N. Sato: Z. Phys. Chem. N.F., 98, 271 (1971).

22) K. Kudo, T. Shibata, G. Okamoto, and N. Sato: Corros. Sci., 8, 809 (1968).

23) W. E. O'Grady: J. Electroch. Soc., 127, 555 (1980).

24) H. H. Uhlig: Z. Elektroch., 62, 626 (1958).

25) B. Kabanov, R. Burstein and Frumkin: Discussions Faraday Soc., 1, 259 (1947).

26) H. Uhlig, and T. O'Connor: J. Electroch. Soc., 102, 562 (1955).

27) R. P. Frankenthal: ibid., 116, 580 (1969).

28) M. A. Gershaw, and R. S. Sirohi: ibid., 118, 1558 (1971).

29) T. P. Hoar: ibid., 117, 17c (1970).

30) C. L. McBee, and J. Kruger: Electrochimica Acta, 17, 1337 (1971).

31) G. Okamoto: Corrosion Sci., 13, 471 (1973).

32) J. S. Leach: Surf. Sci., 53, 257 (1975).

33) G. Okamoto, and T. Shibata: Nature, 206, 1350 (1965).

34) G. Okamoto, et al., Proc. 2nd Internat. Congress Metallic Corrosion, p. 558, Nat. Assoc. Corr. Eng., Houston, TX, 1966

35) W. Vedder, and D. A. Vermilyea: Trans. Farad. Soc., 65, 561 (1969).

36) R. S. Alwitt: J. Electroch. Soc., 121, 1322 (1974).

37) S.F. Bubar and D. A. Vermilyea: J. Electroch. Soc., 113, 892 (1966).

38) K. J. Vetter: Z. Elektroch., 55, 274 (1951).

39) K. J. Vetter: Z. Physik. Chem., 202, 1 (1953).

40) U. F. Franck and K. G. Weil: Z. Elektrochem., 56, 814 (1952).

41) W. J. Muller: Z. Elektrochem., 30, 401 (1922).

42) J. O'M. Bockris, A. K. N. Reddy and B. Rao: J. Electroch. Soc., 113, 1133 (1966).

43) K. Schwabe: Electrochim. Acta, 3, 186 (1960).

44) U. Ebersbach, A. Schwabe, and K. Ritter: Electrochim. Acta, 12, 927 (1967).

45) W. A. Muller: J. Electroch. Soc., 107, 157 (1960).

46) K. J. Vetter: Z. Elektroch., 58, 230 (1954).

47) K. G. Weil: Z. Elektrochem., 59, 711 (1955).

48) M. Nagayama and M. Cohen: J. Electroch. Soc., 109, 781 (1962).

49) D. M. Brasher and A. H. Kingsbury: Trans. Faraday Soc. ,54, 1214 (1958).

50) J. Kruger, and J. P. Calvert: J. Electroch Soc., 114, 43 (1967). 
51) N. Cabrera and N. Mott: Rep. Progr. Phys., 12, 163 (1949).

52) N. Sato and M. Cohen: J. Electroch. Soc., 111, 52 (1963).

53) A. T. Fromhold: in "Passivity of Metals", R. Frankenthal and J. Kruger, Eds., The Electroch. Soc., Princeton (1978), p. 59.

54) D. J. Wheeler, B. D. Cahan, C. T. Chen, and E. Yeager: ibid., p. 546.

55) J. W. Schultze: ibid., p. 82.

56) "Passivity of Metals and Semiconductors", N. Fromant, ed., Elserier, Amsterdam, 1983.

57) J. Kruger, in "Passivity and Its Breakdown on Iron and Iron Based Alloys", R. Staehle and H. Okada, Eds., Nat. Assoc. Corr. Eng., Houston, TX (1976), p. 91.

58) J. R. Galvele, J. B. Lumsden and R. W. Staehle: J. Electrochem. Soc., 125, 1204 (1978).

59) M. Janik-Czachov, G. G. Wood and G. E. Thompson: Brit. Corr. J., 15, 154 (1980).

60) K. J. Vetter and H. H. Strehblow: Ber. Bunsenges. Physik. Chem., 75, 449 (1970).

61) J. Horvath and H. H. Uhlig: J. Electroch. Soc., 115, 791 (1968).

62) E. A. Lizlovs and A. P. Bond: J. Electroch. Soc., 122, 719 (1975).

63) H. Kaesche: Z. Physik., Chem., N.F., 34, 87 (1962).

64) H. Böhni, and H. H. Uhlig: J. Electroch. Soc., 116, 906 (1969).

65) Ya. M. Kolotyrkin: J. Electroch. Soc., 108, 209 (1961).

66) Z. A. Foroulis and M. J. Thubrikar: Electrochim. Acta, 21, 225 (1976).

67) Z. A. Foroulis and M. J. Thubrikar: Werkst. Korros., 26, 350 (1975).

68) H. Leckie and H. H. Uhlig: J. Electrochem. Soc., 113, 1262 (1966).

69) T. Suzuki and Y. Kitamura: Corrosion, 28, 1 (1972).

70) B. Kabanov, R. Burstein and A. Frumkin: Discussions Farraday Soc., No. 1, 259 (1947).

71) Ya. M. Kolotyrkin and L. I. Freiman: Dokl. Akad. Nauk SSSR, 162, 376 (1965).

72) L. I. Freiman and Ya. M. Kolotyrkin: Corros. Sci., 5, 199 (1965).

73) Ya. M. Kolotyrkin, et al.: Dokl. Akad. Nauk SSSR, 148, 1106 (1963).

74) A. B. Ijzermans: Corros. Sci., 10, 607 (1970).

75) L. I. F4eiman and Ya. M. Kolotyrkin: $Z$. Metallov., 2, 488 (1966).

76) J. R. Galvele and S. M. DeMichelli: Corros. Sci., 10, 795 (1970).

77) S. M. DeMichelli and J. R. Galvele: Metal- lurgia- $A B M, 27,589$ (1971).

78) A. Broli, H. Holtan and T. B. Andreasses: Werkst. Korros., 27, 497 (1976).

79) N. Sato, T. Nakagawa, K. Kudo, and M. Sakashita: "Localized Corrosion" p. 447, NACE, Houston, TX (1974).

80) T. P. Hoar and W. R. Jacob: Nature, 216, 1299 (1967).

80) T. P. Hoar, and W. R. Jacob: Nature, 216, 1299 (1967).

81) Z. A. Foroulis and M. J. Thubrikar: $J$. Electroch. Soc., 122, 1962 (1975).

82) M. Pourlaix: Corrosion, 27, 449 (1971).

83) T. Suzuki, M. Yamabe and Y. Kitamura: Corrosion, 29, 18 (1973).

84) I. L. Rosenfeld and I. S. Danilov: Corros. Sci., 7, 129 (1967).

85) D. A. Jones, and B. E. Wilde: Corros. Sci., 18, 631 (1978).

86) U. R. Evans, L. C. Bannister and S. C. Britton: Proc. Roy. Soc., A132, 367 (1931).

87) J. A. Richardson and G. C. Wood: J. Electroch. Soc., 120, 193 (1973).

88) T. P. Hoar, D. C. Mears and G. P. Rothwell: Corros. Sci., 5, 279 (1965).

89) M. A. Heine, D. S. Keir and M. S. Pryor: $J$. Electroch. Soc., 112, 29 (1965).

90) T. P. Hoar: Corros. Sci., 7, 335 (1967).

91) N. Sato: Electrochimica Acta, 19, 1683 (1971).

92) Z. A. Foroulis: J. Electroch. Soc., 123, 841 (1976).

93) S. Dalbek, and R. T. Foley: J. Electroch. Soc., 123, 1775 (1976).

94) K. E. Heusler and L. Fischer: Werkst. Korros., 27, 697 (1976).

95) M. Janik-Czachor: Werkst. Korros., 30, 255 (1979).

96) H. H. Strehblow, B. Titze and B. P. Loechel: Corros. Sci., 19, 1047 (1979).

97) E. B. E. Wilde and Williams: Electrochem. Acta, 16, 1971 (1971).

98) G. C. Wood, et al.: in "Passivity of Metals", R. P. Frankenthal and J. Kruger, Eds., The Electrochem. Soc., Princeton, NJ (1978), p. 973.

99) B. F. Brown: in "Theory of Stress Corrosion Cracking in Alloys", J. C. Scully, Ed., North Atlantic Treaty Organization, Brussels (1971), p. 186.

100) B. Wilde and E. Willimas: J. Electroch. Soc., 118, 1057 (1971).

101) E. A. Lizlovs and A. P. Bond: Corrosion, 31, 219 (1975).

102) V. A. Gilman and Ya. M. Kolotyrkin: Dokl. Akad. Nauk SSSR, 153, 640 (1962). 